\title{
The Gasteromycetes of the Aland Islands, SW Finland: an annotated checklist
}

\author{
CARL-ADAM HÆGGSTRÖM
}

\begin{abstract}
HÆGGSTRÖM, C.-A. 1997: The Gasteromycetes of the Aland Islands, SW Finland: an annotated checklist. - Karstenia 37:11-18. Helsinki. ISSN 0453-3402

Both herbarium specimens and published data on the Gasteromycetes s.l. of the Aland Islands are treated. Altogether, 37 species have been reported which is a little more than half of the total species number of Finland. Seven species, namely Bovista nigrescens, B. plumbea, Calvatia excipuliformis, C. utriformis, Lycoperdon perlatum, $L$. pyriforme and Phallus impudicus seem to be common or fairly common in the Aland Islands. Eight species, viz. Geastrum elegans, G. floriforme, G. schmidelii, G. striatum, Langermannia gigantea, Lycoperdon echinatum, Melanogaster ambiguus and Tulostoma brumale are listed as threatened in Åland.
\end{abstract}

Key words: Åland Islands, checklist, Finland, Gasteromycetes

Carl-Adam Haggström, Department of Ecology and Systematics, P.O. Box 7, FIN00014 University of Helsinki, Finland

\section{Introduction}

The written knowledge of the Gasteromycetes of the Aland Islands has hitherto been both scattered and rather insignificant. In his papers on Basidiomycetes of Finland, P.A. Karsten (1889, $1893,1898)$ enumerates 27 species, some of them dubious, or defined differently than now, of the Gasteromycetes s.l. found within the present boundaries of Finland; none of them were mentioned to occur in Åland.

Ulvinen (1976) enumerated 50 species of Gasteromycetes s.1. found in Finland. Three further species, whose status in Finland was uncertain, were also included. Since then, several more species have been found and the total number of Gasteromycetes s.l. species found in Finland is now about 70 .

This paper deals with the Gasteromycetes s.1. found in the Aland Islands. In preparing the paper, I have studied all available herbarium specimens collected in Åland, except for a few Geas- trum specimens in the herbarium of Dr. Stellan Sunhede which are treated in detail in his doctoral thesis (Sunhede 1989). Besides my own collections (included in $\mathrm{H}$ ), I have obtained specimens from the following herbaria: H, OULU, TUR, TURA and UPS. No specimens were sent from GB, KUO, LD and S. Furthermore, I have tried to find published information on Gasteromycetes from Åland.

Older published data are rarely accompanied by preserved material in herbaria. Therefore, published information on certain species may contain wrong determinations regarding the species. Lacking methods for controlling such cases, I decided to report this information according to the original papers. A few of the determinations are obviously wrong and these are discussed in each case. Some of the herbarium specimens were too young to identify their species, or even their genus.

Microscopic characters were studied in most herbarium specimens, among others all those be- 
longing to Lycoperdaceae. The spores and capillitial hyphae were studied both in lactophenol with or without cotton blue and Melzer's reagent. The tiny warts or spines of Lycoperdon and Bovista spores were better seen using Melzer's reagent.

\section{The Åland Islands}

The Åland Islands comprise an archipelago of more than 6000 islands at the edge of the northern Baltic Sea. Biogeographically this archipelago belongs to the hemiboreal zone (Ahti et al. 1968). The bedrock mostly consists of acid rapakivi granite and other granites and of gneisses, too (Hausen 1964). The soil is rich in calcium because of the Ordovician limestone which originates from the bottom of the Bothnian Sea and Lumparn Bay (Brenner 1930, Hausen 1964). Due to this calcium-rich soil and the fairly favourable climate, the vegetation is in many places luxuriant and rich in species. The calcicolous element of both fungi and plants is prominent. Many species grow here at their northernmost limits in the Baltic Sea area. The influence of man upon nature has been intense, although pasturing activities have been reduced during this century. However, grazing in woods and seminatural habitats, such as wooded meadows, wooded pastures and seashore meadows, is much more common in Åland than in other parts of Finland.

\section{The investigation of the Alandian Gasteromycete flora}

The first piece of information regarding Gasteromycetes in Åland is the specimen of Lycoperdon pyriforme collected in the commune of Jomala by P.A. Karsten in 1881 (H). He did not, however, mention this record in his papers (Karsten 1889, 1893, 1898). Therefore, the first published information is a short note on Phallus impudicus (Elfving 1907) based on specimens collected in 1906 in Jomala (at least three collections in H; cf. Luther 1947a). Two more short notes on the same species were published by Brenner (1908) and Palmgren (1908).
Knowledge of the Gasteromycetes of the Åland Islands was built up slowly. By 1930 only three species were known from this area. Due to the efforts of Ole Eklund, Ernst Häyrén, Lauri E. Kari, Carl Th. Mörner and Göran Stenlid, six new Åland species were found during the 1930s. One further species, Geastrum pectinatum was probably also found during this period, because a note on its occurrence in the Aland Islands was published by Ingelström (1940).

During the 1940s several persons (mostly the same as during the 1930s and Otto von Schulmann) contributed to our knowledge of the Alandian Gasteromycete flora. Twelve or thirteen new species were found.

During the following two decades a slight decline in collecting activity occurred. Only four new species were found. During the 1970s and 1980s, attention was again paid to the fungi of Åland. This is partly the result of the efforts of the present author, who collected Gasteromycetes whenever he found them. Also, many other persons collected Gasteromycetes. These efforts contributed eleven new species of the Alandian Gasteromycete flora.

In the mid 1990s 37 species had been reported from the Aland Islands. This is a little more than half of the total species number of Finland. Several Gasteromycete species found in other parts of Finland, have eluded the collector's eye in Åland. This regards especially the hypogeous genus Hymenogaster and some Bovista species, particularly $B$. paludosa Lév. which presumably may be present in some of the Alandian rich fens.

\section{List of taxa}

The communes are abbreviated: $\mathrm{Br}=$ Brändö, $\mathrm{Ec}=$ Eckerö, $\mathrm{Fi}=$ Finström, Fö = Föglö, $\mathrm{Ge}=$ Geta, Ha = Hammarland, Jo = Jomala, Kö = Kökar, $\mathrm{Ku}=$ Kumlinge, Le = Lemland, $\mathrm{Ma}=$ Mariehamn, $\mathrm{Sa}=$ Saltvik, So $=$ Sottunga, $\mathrm{Su}=$ Sund, Vå = Vårdö. Whenever possible, the coordinates according to the Finnish uniform grid system (Grid $27^{\circ} \mathrm{E}$ ) are given with an accuracy of $10 \mathrm{~km}(3+2$ numbers $)$, or $1 \mathrm{~km}(4+3$ numbers). Some information is too general for determining accurate co-ordinates. 


\section{Lycoperdales \\ Geastraceae}

Geastrum elegans Vittad. - Le: Järsö, on the seashore opposite the island Bötesholm (6677:110-1), 17.IX.1948, G. Stenlid 639 (UPS; det. S. Sunhede). — Literature: Sunhede (1989), Ulvinen (1994).

Geastrum fimbriatum Fr. - Recorded seven times (Ec, Fi, Jo, Le, Su and Vå; H, TURA, UPS). First record: Ec: Torp, S of Skeppsvik, beneath a hazel shrub (669:08), 18.VI.1945, G. Stenlid (H). According to Stenlid (1947), the date was 20.VI.1945. - The species was found in deciduous stands, under a spruce and in a pine wood on sandy soil with the quite high $\mathrm{pH}$ of 6.8 (Huhtinen 1992). Three of the finds were from the calcareous area of Lumparn Bay. - Literature: Stenlid (1947), Huhtinen (1992).

Geastrum floriforme Vittad. - Jo: Hammarudda, on gravelly soil between junipers near the seashore (668:09), 4.IX.1949, G. Stenlid (UPS; det. S. Sunhede). — Literature: Sunhede (1989), Ulvinen (1994).

Geastrum pectinatum Pers. - Recorded 13 times (Jo, Le and Vå; H, OULU, TUR, UPS, herb. Sunhede). First record: Åland according to N. Stenlid (Ingelström 1940). — This species was mostly found in spruce woods. It usually grows in the needle litter, or on abandoned or dying ant-hills. A few finds were from luxuriant deciduous stands. All finds except two were located on the two adjacent islands Nåtö and Järsö in Le. - Literature: Ingelström (1940), von Schulmann (1961), Sunhede (1989).

Geastrum quadrifidum Pers.: Pers. - Recorded 14 times (Ec, Le and Vå; H, TUR, UPS). First record: Le: Nåtö $(667: 10$ or 668:10), 16.VI.1946 (Stenlid 1947). — The species was recorded in mixed or spruce woods. The localities were often rather moist. One find was on an abandoned ant-hill. - Literature: Stenlid (1947), von Schulmann (1958, 1961).

Geastrum schmidelii Vittad. (syn. G. nanum Pers.) — Föglö: Björkör, sandy sheep pastured meadow, at a boulder about $40 \mathrm{~m} \mathrm{~N}$ of the main building (6667:121), 26.VIII.1972, C.-A. Hæggström $(\mathrm{H})$. - Not seen since, although searched for in this place several times during 1973-95. - Literature: Hæggström (1979), Sunhede (1989), Ulvinen (1994).

Geastrum striatum DC. - Kökar: Kyrkogårdsö, on and at an ant-hill on an old cow dung heap at Linus' cow shed (6674:156), 6.VI.1974, C.-A. Hæggström (H). — Literature: Sunhede (1989), Ulvinen (1994).

\section{Lycoperdaceae}

Bovista pusilliformis (Kreisel) Kreisel - Only found twice. First record: Le: Nåtö, in a wooded meadow about $200 \mathrm{~m}$ E of Norrbacka (6680:109), 22.VIII.1971, C.-A. Hæggström (H). - Each collection consists of one somewhat unripe fruit body, but the microscopical characters are typical of B. pusilliformis as described by Kreisel $(1962,1967)$. Especially the numerous minute pores and amphiseptal branching of the capillitial hyphae are characteristic features of this species as described by Kreisel (1962, 1967). According to Mr. M. Jeppson (Trollhättan, Sweden, letter in 1990), both specimens belong to $B$. aestivalis (Bonord.) Demoulin (Demoulin 1979). This species has a rather variable morphology, for instance capillitial hyphae with small and large pores, and a wide ecological amplitude occurring on dry open sandy soil, or on mull and clayey soils in deciduous woods. In my opinion, the variability both in morphology and ecology of $B$. aestivalis sensu Demoulin seems to be too great to make it a single species. Therefore, in accordance with Kreisel $(1962,1967,1987)$ and Gross et al. (1980), I consider B. pusilliformis (Kreisel) Kreisel as a distinct species (cf. also Pegler et al. 1995). Literature: Hæggström (1997).

Bovista nigrescens Pers.: Pers. - Recorded 20 times (Ec, Fi, Kö, Le and Sa; H, TUR). First record: Ec: Storby, hillock with junipers (670:08), 13.VII.1935, E. Häyrén (H; confirm. F.-E. Eckblad 1963). - This species was often found in grazed meadows and pastures. Other localities are hazel stands, deciduous and mixed woods, on the spruce needle mat under a large 
spruce and on Fucus wrack on the seashore beneath Alnus glutinosa. - Literature: Stenlid (1947), von Schulmann (1955).

Bovista plumbea Pers.: Pers. - Recorded 31 times (Br, Ec, Fi, Ge, Jo, Ku, Kö, Le, Sa and Su; H, TUR, TURA). First record: Ec, 15.VIII.1937, A. Södergård (H; det. C.-A. Hæggström 1990). - This species was found on open ground in pastures, at roadsides and in lawns. It is often found together with $B$. nigrescens. - Literature: Eklund (1943), Stenlid (1947), von Schulmann (1955).

Bovista dermoxantha Vittad. (syn. B. pusilla (Batsch) Pers.) - Stenlid (1947) reported two finds of Lycoperdon pusillum from Le. Specimens in UPS from one of the localities belong to Bovista limosa (see below). The other find from the island of Kungsholm (6685-6:114), 20.IX. 1946 (Stenlid 1947) may perhaps refer to $B$. limosa, or some other Bovista or Lycoperdon species. As no herbarium specimen is available its affiliation to the species cannot be verified. - Literature: Stenlid (1947).

Bovista limosa Rostr. - Le: Norrby, Segelgrundet (6686:115), 20.IX. 1946 (UPS; det F.-E. Eckblad 1954 (as Bovistella echinella (Pat.) Lloyd), confirm. C.-A. Hæggström 1996). Literature:Stenlid (1947 as Lycoperdon pusillum).

Calvatia excipuliformis (Pers.) Perdeck - Recorded 16 times (Ec, Fi, Fö, Jo, Le and Ma; H, TUR, TURA). First record: Jo: Hammarudda, a meadow near the seashore (668:09), 23.VI.1949, E. Häyrén (H; det N. Malmström). - This species was found in dry and mesic meadows and in deciduous woods. - Literature: von Schulmann $(1955,1958,1961)$.

Calvatia utriformis (Bull.: Pers.) Jaap - Recorded 24 times (Ec, Fi, Fö, Jo, Kö, Le, Sa and So; H, TUR). First record: Ec: Torp, deciduous grove (669:08-9), 14.VI.1937, L.A. Kari (TUR; det. C.-A. Hæggström 1989). — The species was found on sandy seashores, on sandy roads and roadsides, and in dry and mesic meadows. - Literature: Stenlid (1947), von Schulmann (1955).
Langermannia gigantea (Batsch: Pers.) Rostk. - Recorded three times (Br, Ec and Ge). First record: Br: Fiskö, Storholm, possibly 6.VIII.1934, O. Eklund (Luther 1947a). - Although no herbarium specimens are preserved, the determination of this easily recognisable species is almost certain, especially regarding the two finds of the 1980s, which were reported with photographs in the daily press. - Literature: Luther (1947a), Ahti \& Korhonen (1974), Södergårdh (1980, 1987), Tuominen (1987), Ulvinen (1994).

Lycoperdon echinatum Pers.: Pers. - Le: Flaka, hazel grove near the road about $50 \mathrm{~m} \mathrm{~W}$ of the isthmus towards Apalholm (6674:118), 14.IX.1984, Eva Hinder (H). — Literature: Södergårdh (1984), Andersson (1994), Ulvinen (1994).

Lycoperdon ericaeum Bonord. var. ericaeum Recorded 8 times (Le and Su; H). First record: Le: Nåtö, on a flat rock outcrop by the midsummer pole (6680:109), 22.V.1984, C.-A. Hæggström $4754(\mathrm{H})$. - This species was found in rock meadows and other dry meadows. One fruit body was also found on rather dry soil in a light deciduous wood.

Lycoperdon lividum Pers. - Recorded 8 times (Fi, Fö, Le and Su; H). First record: Su: Kastelholm, in a meadow at Jan Karlsgården on the slope towards the seashore (6700:117), 2.X.1982, C.-A. Hæggström 3990a (H). — The species was found in dry meadows.

Lycoperdon molle Pers.: Pers. - Recorded three times (Ha and Le; H, OULU, TUR. First record: Le: Nåtö, Eskskär (6679:105-6), 3.IX.1949, L.E. Kari (TUR; det. group molle by V. Demoulin 1969; det C.-A. Hæggström 1990). - This species was found in deciduous or mixed woods and on a rocky slope in a cut forest.

Lycoperdon nigrescens Pers. - Only recorded twice (Le and So; H). First record: So: Norra byn, mixed forest (668:14), 10.VIII.1974, A. Nordström 311 (H; det. C.-A. Hæggström 1990). - The species was found in a mixed forest and in a dry meadow. 
Lycoperdon perlatum Pers.: Pers. - Recorded 43 times (Ec, Fi, Fö, Ha, Jo, Le, Sa and Vå; H, TUR, TURA). First record: Ec: Storby, spruce wood, 12.VII.1935, Ernst Häyrén (H; det. W. Nyberg; det. V. Demoulin 1974). - This is one of the most common gasteromycete species in Åland. It was found growing among mosses and in the litter in mixed woods with pine and spruce, spruce woods, mixed woods (often below Populus tremula), deciduous woods with ash, birch, oak and hazel, and further on thin humus on rock outcrops, on decaying wood at a roadside, and even on the gravel at roadsides. Literature: Stenlid (1947), von Schulmann (1955).

Lycoperdon pyriforme Schaeff.: Pers. - Recorded 42 times (Ec, Fi, Ha, Jo, Le, Ma and Vå; H, TUR, TURA). First record: Jo, 1.IX.1881, P.A. Karsten 507 (H; det P.A. Karsten 1883; det. V. Demoulin 1976). - Together with L. perlatum one of the most common gasteromycete species in Aland. It is associated with decaying wood, visible or buried in the soil. Of its substrates the following may be mentioned: in cracks and on decaying parts of living trunks of Fraxinus excelsior, Malus sylvestris, Sorbus hybrida and Tilia cordata and on stumps and dead trunks of Alnus glutinosa, Betula sp., Fraxinus excelsior and Quercus robur. A few roadside finds were also made.

Lycoperdon umbrinum Pers.: Pers. - Recorded 10 times (Ec, Le and Vå; H, OULU). First record: Ec, 1948 (von Schulmann 1955). — The species grew in spruce woods and at roadsides in woods. - Literature: von Schulmann (1955).

Vascellum pratense (Pers.: Pers.) Kreisel - Recorded six times (Ec, Jo and Su; H, TURA). First record: Su: Kastelholm, in a meadow at Jan Karlsgården on the slope towards the seashore (6700:117), 2.X.1982, C.-A.Hæggström 3990b (H). - This species was found in rock meadows and other dry meadows.

\section{Mycenastraceae}

Mycenastrum corium (Guers.) Desv. - Ec: Storby, sandy road-side at the post bridge
(6701-2:087), 1.IX.1936, C.T. Mörner (H; UPS). - Literature: Häyrén (1937), Mörner (1937), Ingelström (1940), Ulvinen (1976).

\section{Melanogastrales Melanogastraceae}

Melanogaster ambiguus (Vittad.) Tul. - Le: Nåtö, a wooded meadow in the Nature Reserve about 400 m ENE of Nåtö Biological Station, in the humified base of an ant-hill (6680:109), 30.VIII.1977, C.-A. Hæggström (H). - Not seen since, although searched for in this place every year during 1978-96. - Literature: Hæggström (1981), Ulvinen (1994).

\section{Nidulariales \\ Nidulariaceae}

Crucibulum laeve (Huds.) Kambly - Recorded 10 times (Kö, Le and Vå; H). First record: Le: Nåtö (667-8:10), 13.IX.1946 (Stenlid 1947). This species was found on decaying twigs of $\mathrm{Al}$ nus glutinosa and Corylus avellana, on the trunk of an old apple tree, on the spruce needle mat in a spruce wood, and on the gravelly soil at a car parking place. - Literature: Stenlid (1947).

Cyathus olla (Batsch: Pers.) Pers. - Le: Nåtö, on a decaying piece of chip board in the hazel grove at the Nåtö Biological Station (6680:109), 17.VIII.1973, C.-A. Hæggström (H).

Cyathus striatus (Huds.) Pers. - Recorded 7 times (Ha, Jo, Le, Ma and Su; H, TUR, TURA, UPS). First record: Le: Flaka, Apalholmen (667:11), 19.IX.1946. G. Stenlid (UPS; confirm C.-A. Hæggström 1996; according to Stenlid (1947), the habitat was on the soil in a dense hazel stand). - The species was mostly found on decaying wood (e.g. Alnus glutinosa). - Literature: Stenlid (1947), von Schulmann (1961).

Nidularia deformis (Willd.: Pers.) Fr. (syn. N. farcta (Roth: Pers.) Fr.) — Vå: Vargata, NNE of Pellas Norråker, on a heap of old timber (669670:13), 3.XI.1962, P. Olofsson (OULU; confirm. C.-A. Hæggström 1990). 


\section{Sphaerobolaceae}

Sphaerobolus stellatus Tode: Pers. - Vå: Vargata, NNE of Pellas Norråker, on a heap of old timber (669-670:13), 3.XI.1962, P. Olofsson (OULU; confirm. C.-A. Hæggström 1990).

\section{Phallales \\ Phallaceae}

Phallus impudicus L.: Pers. - Recorded 40 times (Br, Ec, Fi, Fö, Ge, Ha, Jo, Ku, Le and Su; H, TUR, TURA). First records: Jo, 1906, H. Snellman (H; confirm. C.-A. Hæggström 1989) and Fö: Näfversholm, 1906 (Brenner 1908). The common stinkhorn has attracted the attention of botanists and laymen for most of this century. Therefore, it is the most frequently reported species in the literature. This fungus has been often found in luxuriant deciduous woods and wooded meadows. It has also been found in spruce woods, a mixed pine wood and in a lawn. - Literature: Elfving (1907), Brenner (1908), Palmgren (1908, 1921), Suomalainen (1916), Lindberg (1921), Hintikka (1931, 1933), Häyrén (1944), Luther (1947a, 1947b), Stenlid (1947), Södergård (1948), von Schulmann (1955, 1961), Eklund (1958), Tuomikoski (1959), Lange (1974), Ulvinen (1976), Hæggström (1981, 1996), Becker (1983), Svrček (1983), Härkönen (1984), Ryman \& Holmåsen (1984), Andersson (1989) and Korhonen (without year).

\section{Sclerodermatales \\ Sclerodermataceae}

Scleroderma areolatum Ehrenb. - Only recorded twice (Ec and Ma; TURA). First record: Ec, 11.IX. 1954 (von Schulmann 1955). - Literature: von Schulmann $(1955,1961)$.

Scleroderma bovista Fr. - Recorded three times (Ec and Vå; H, TUR). First record: Ec, 13.IX. 1954 (von Schulmann 1955). - Literature: von Schulmann $(1955,1961)$.

According to von Schulmann (1961) an unknown Scleroderma species was found by him in Mariehamn: Ytternäs in 1958. The collected fruit bodies in $\mathrm{H}$ represent, however, the ascomycete Elaphomyces asperulus Vittad. (det. C.A. Hæggström 1989).

\section{Tulostomatales Tulostomataceae}

Tulostoma brumale Pers.: Pers. - Kö: Österbygge, Storrevet (665:17), 20.VI.1948, G. Stenlid (UPS; confirm. C.-A. Hæggström 1996). Literature: Andersson (1950), Kallio \& Heikkilä (1963), Ulvinen (1976, 1994).

\section{Boletales \\ Rhizopogonaceae}

Rhizopogon obtextus (Spreng.) Rauschert (syn. $R$. luteolus Fr. \& Nordh.) - Recorded three times (Ec, Ma and Vå; H). First record: Ma: Ytternäs, VIII.1905, (668:10), M. Bergström (or Brändström, cf. Fries 1909) (UPS; det. Th.M. Fries, confirm. M.P. Martin 1992). - Literature: Fries (1909), von Schulmann (1955, 1961).

Rhizopogon roseolus (Corda) Th. Fries. - Only recorded twice (Ec, Sa). First record: Ec, 1948 (von Schulmann 1955, 1961). - It is doubtful whether Rhizopogon roseolus belongs to the mycoflora of Finland (Eckblad \& Lange 1992). The specimens found by von Schulmann may perhaps belong to Rhizopogon rubescens Tul., which is fairly common in Finland (Ulvinen 1976, Eckblad \& Lange 1992). Most of the Finnish specimens named $R$. rubescens were recently determined as $R$. vulgaris (Vittad.) M. Lange by Maria P. Martin (Barcelona; Spain). She regards $R$. roseolus as synonymous with $R$. rubescens.

\section{Concluding remarks}

The Gasteromycete flora of Aland is fairly rich in these species. The majority of the species are found in seminatural habitats such as wooded meadows and pastures of different kinds. The following seven species seem to be common, or fairly common in the Aland Islands: Bovista nigrescens, B. plumbea, Calvatia excipuliformis, 
C. utriformis, Lycoperdon perlatum, L. pyriforme and Phallus impudicus. Several species are obviously rare, but among those which have been found only once or twice, some may be quite common. They have apparently eluded the collectors, because of their small size, e.g. Nidularia deformis and Sphaerobolus stellatus. The following 12 (or 13) species have been recorded only once: Geastrum elegans, G. floriforme, $G$. schmidelii, G. striatum, Bovista dermoxantha (dubious), B. limosa, Lycoperdon echinatum, Mycenastrum corium, Melanogaster ambiguus, Cyathus olla, Nidularia deformis, Sphaerobolus stellatus and Tulostoma brumale.

The following gasteromycete species are listed as threatened in Aland (Rassi et al. 1992, Ulvinen 1994):

- endangered: Geastrum elegans, G. floriforme, G. schmidelii

- vulnerable: Geastrum striatum, Lycoperdon echinatum

- in need of monitoring, rare: Langermannia gigantea

- in need of monitoring, insufficiently known: Melanogaster ambiguus, Tulostoma brumale

Gasteromycetes have been found in all the Alandian communes, with the exception of Lumparland. Specimens have been collected rather irregularly and from half of the communes only one to six collections are preserved in the herbaria. Surprisingly, the mainland communes of Hammarland, Geta and Saltvik belong to these inadequately known communes. The only communes with at least 20 collections are Eckerö, Jomala, Finström and Lemland. The rather large number (139) of collections in Lemland is partly due to the fact that some areas of the commune were quite thoroughly investigated by Göran Stenlid during the 1940s and since 1964 by several persons, among them the author, working at the Nåtö Biological Station. In fact, only a very few areas in Aland have been fairly closely investigated, among these areas are Storby in Eckerö and Nåtö, Apalholmen and Herrö in Lemland.
Acknowledgements. My sincere thanks are due to the keepers of the herbaria mentioned, to Dr. Stellan Sunhede for information on the Geastrum species, and to Dr. Tauno Ulvinen, with whom I have had several fruitful and interesting discussions on fungi.

\section{References}

Ahti, T., Hämet-Ahti, L. \& Jalas, J. 1968: Vegetation zones and their sections in northwestern Europe. - Ann. Bot. Fennici 5:169-211.

A[hti], T. \& K[orhonen], H. [pro M.] 1974: Jättiläiskuukunen. - Sienilehti 26(4):15.

Andersson, O. 1950: Larger fungi on sandy heaths and sand dunes in Scandinavia. - Bot. Not. Suppl. 2(2):1-89, 9 plates.

Andersson, O. 1989: Stinksvampen, Phallus impudicus, i Norden. - Svensk Bot. Tidskr. 83:219-241.

Andersson, O. 1994: Igelkottsröksvamp och slöjröksvamp. Ekologi och utbredning i Norden. - Svensk Bot. Tidskr. 88:167-183.

Becker, G. 1983: Champignons. - 319 pp. Gründ, Paris.

Brenner, M. 1908: Mykologiska notiser. - Meddelanden Soc. Fauna Flora Fennica 34:26, 222.

Brenner, W. 1930: Beiträge zur edaphischen Ökologie der Vegetation Finnlands. I. Kalkbegünstigte Moore, Wiesen und Weisenwälder. - Acta Bot. Fennica 7:1-97.

Demoulin, V. 1979: The typification of Lycoperdon described by Peck and Morgan. - Beih. Sydowia, Ann. Mycol. Ser. II, 8:139-151, plate I-III.

Eckblad, F.-E. \& Lange, M. 1992: Rhizopogonaceae Gäumann \& Dodge. - In: Hansen, L. \& Knudsen, H. (eds.), Nordic macromycetes 2: 67-68. Nordsvamp, Copenhagen.

Eklund. O. 1943: Zur Pilzflora des Schärenarchipels SW-Finnlands. - Memoranda Soc. Fauna Flora Fennica 18:2-21.

Eklund, O. 1958: Die Gefässpflanzenflora beiderseits Skiftet im Schärenarchipel Südwestfinnlands. Kirchspiele Korpo, Houtskär, Nagu, Iniö, Brändö, Kumlinge, Sottunga und Kökar. - Bidrag till Kännedom af Finlands Natur och Folk 101:1324, 85 maps.

Elfving, F. 1907: Phallus impudicus L. i Finland. - Meddelanden Soc. Fauna Flora Fennica 33:32, 188

Fries, T.M. 1909: Skandinaviens tryfflar och tryffelliknande svampar. - Svensk Bot. Tidskr. 3:223300.

Gross, G., Runge, A. \& Winterhoff, W. 1980: Bauchpilze (Gasteromycetes s.l.) in der Bundesrepublik und Westberlin. - Beih. Zeitschr. Mykol. 2:1220.

Hæggström, C.-A. 1979: Geastrum nanum found in Finland. - Karstenia 19:19-21.

Hæggström, C.-A. 1981: Melanogaster ambiguus found in Finland. - Karstenia 21:9-14.

Hæggström, C.-A. 1997: Bovista pusilliformis found in Finland. - Memoranda Soc. Fauna Flora Fennica 73.

Härkönen, M. 1984: Haisusieni, Phallus impudicus. In: Härkönen, M. \& Kotiranta, H. (eds.), Sie- 
nestäjän tietokirja: 252. Oy Valitut Palat - Reader's Digest Ab, Helsinki.

Hausen, H. 1964: Geologisk beskrivning över Landskapet Åland. - Skrifter Ålands Kulturstiftelse 4:1196, 45 plates, 1 map. Mariehamn.

Häyrén, E. 1937: [Mycenastrum corium Desv., ny för Finland.] - Memoranda Soc. Fauna Flora Fennica 13:101.

Häyrén, E. 1944: Lavar och svampar. - In: Palmgren, A., Naturskyddet på Åland och dess framtida utveckling. Acta Soc. Fauna Flora Fennica 63(4):40-42.

Hintikka, T.J. [1931]: Sienimaantietecllisestä (mykogeograafisesta) tutkimustyöstä, varsinkin Suomessa. - 49 pp. [Helsinki, publ. by the author.]

Hintikka, T.J. 1933: Über die Verbreitung von Phallus impudicus L. in Finnland. - Friesia 1:88-90.

Huhtinen, S. 1992: Virolais-suomalainen toivioretki. Sienilehti 44:19-23.

Ingelström, E. 1940: Svampflora. Med 126 svampfotografier. - 216 pp., 64 plates, XVI pp. Nordisk Rotogravyr, Stockholm.

Kallio, P. \& Heikkilä, H. 1963: Some Macromycetes from Yyteri sand dunes in SW-Finland. - Karstenia 6-7:111-112.

Karsten, P.A. 1889: Kritisk öfversigt af Finlands Basidsvampar (Basidiomycetes; Gastero- \& Hymenomycetes). - Bidrag till kännedom af Finlands natur och folk 48:1-470.

Karsten, P.A. 1893: Kritisk öfversigt af Finlands Basidsvampar Tillägg II. - 32 pp. Helsingfors.

Karsten, P.A. 1898: Kritisk öfversigt af Finlands Basidsvampar Tillägg III. - $36 \mathrm{pp}$. Helsingfors.

Korhonen, M. (without year): Sieniä silmien iloksi. 12 postikorttia kiinnostavista ja harvinaisista sienilajeista. - Lieto. 12 postcards.

Kreisel, H. 1962: Die Lycoperdaceae der Deutschen Demokratischen Republik. Floristische und taxonomische Revision. - Feddes Repert. 64:89201.

Kreisel, H. 1967: Taxonomisch-pflanzengeographische Monographie der Gattung Bovista. - Beih. Nova Hedwigia 25:1-244, 70 figs.

Kreisel, H. 1987: Pilzflora der Deutschen Demokratischen Republik. Basidiomycetes (Gallert-, Hutund Bauchpilze). - 281 pp. Gustav Fischer Verlag, Jena.

Lange, L. 1974: The distribution of Macromycetes in Europe. - Dansk Bot. Arkiv 30(1):1-105.

Lindberg, H. 1921: [Phallus impudicus på Åland.] Meddel. Soc. Fauna Flora Fennica 46:10, 227.

Luther, H. 1947a: Beobachtungen über Phallus impudicus (L.) Pers. in Finnland. - Memoranda Soc. Fauna Flora Fennica 23:42-59.

Luther, H. 1947b: Haisusienestä (Phallus impudicus [L.] Pers.) Suomessa ja muualla. - Luonnon Tutkija 51:5-10.

Mörner, C.T. 1937: Orientering över gasteromyceten Mycenastrum corium (Guers.) Desv. (Nyligen funnen även å finländskt område.) - Svensk Bot. Tidskr. 31:206-214.
Palmgren, A. 1908: [Phallus impudicus på Åland.] Meddel. Soc. Fauna Flora Fennica 34:26-27, 222.

Palmgren, A. 1921: [Phallus impudicus på Åland.] Meddel. Soc. Fauna Flora Fennica 46:11, 227.

Pegler, D.N., Læssøe, T. \& Spooner, B.M. 1995: British puffballs, earthstars and stinkhorns. An account of the British gasteroid fungi. - Royal Botanic Gardens, Kew. 255 pp.

Rassi, P., Kaipiainen, H., Mannerkoski, I. \& Ståhls, G. 1992: Uhanalaisten eläinten ja kasvien seurantatoimikunnan mietintö. - Komiteamietintö 1991(30): 1-328. Ympäristöministeriö, Helsinki.

Ryman, S. \& Holmåsen, I. 1984: Svampar. En fäldhandbok. - 718 pp. Interpublishing AB; Stockholm.

Schulmann, O. von 1955: Pilzstudien in Finnland. Karstenia 3:17-68.

Schulmann, O. von 1958: Pilzstudien in Finnland II. Karstenia 4:27-62.

Schulmann, O. von 1961: Zur Kenntnis der Basidiomyceten Finnlands. - Karstenia 5:5-99.

Södergård, A. 1948: Stinkmurklan. - Åländsk Odling 9:93-100.

[Södergårdh, C.-E.] 1980: Rekordtungt på matsedeln. Aland 6.IX.1980, 90(106):8. Mariehamn.

Södergårdh, C.-E. 1984: Sällsynt svamp hittad i Flaka. Åland 18.IX.1984, 94(142):8. Mariehamn.

[Södergårdh, C.-E.] 1987: Jättesvamp och sjuklöver. Alland 10.IX.1987, 97(170):12. Mariehamn.

Stenlid, G. 1947: Några anteckningar om Ålands svampflora. - Memoranda Soc. Fauna Flora Fennica 23:82-90.

Sunhede, S. 1989: Geastraceae (Basidiomycotina). Morphology, ecology, and systematics with special emphasis on the North European species. Synopsis Fungorum 1:1-534. Fungiflora, Oslo.

Suomalainen, E.W. 1916: Kolme uutta haisusieni(Phallus impudicus L.) löytöä Suomesta. - Meddelanden Soc. Fauna Flora Fennica 42:26-27, 173.

Svrček, M. 1983 (1988): The illustrated book of mushrooms and fungi. - 311 pp. Octopus Books, London.

Tuomikoski, R. 1959: Sienet värikuvina. - Werner Söderström Osakeyhtiö. Porvoo \& Helsinki. 246 pp.

[Tuominen, H.] 1987: Jättesvamp för Linda i Geta. Tintin-svamp eller jätterök? - Nya Åland 10.IX.1987, 7(104):1, 20.

Ulvinen, T. 1976: Kupusienet - Gasteromycetes. - In: Ulvinen, T. (ed.), Suursieniopas: 240-257. Suomen Sieniseura, Helsinki.

Ulvinen, T. 1994: Suomen uhanalaiset kupusienet. Sienilehti 46:69-89.

\section{Received on 21 February 1996}

